\title{
Synthesis Octyl P-Methoxycinnamate as Sunblock by Transesterification Reaction with the Starting Material Ethyl P- Methoxycinnamate
}

\author{
Suzana*, Nunuk Irawati, Tutuk Budiati \\ Alumnus of Faculty of Pharmacy, Universitas Airlangga, Surabaya \\ Department of Pharmaceutical Chemistry, Faculty of Pharmacy Universitas Airlangga,
}

\begin{abstract}
Synthesis octyl p-methoxycinnamate substance as sunblock, has been done by transesterification reaction. The starting material of the reaction was ethyl $p$ methoxycinnamate isolated from Kaempferia galanga L.The transesterification reaction was carried out by reacting ethyl $p$-methoxycinnamate with octanol. The product was identified by UV-VIS, Infra Red and Mass Spectroscopy. The result of measurements on erythemic \%T at various concentrations demonstrate that octyl $\mathrm{p}$-methoxycinnamate is applicable as a sunblock compound.
\end{abstract}

Keywords: octyl p-methoxycinnamate, transesterification, ethyl p-methoxycinnamate, sunblock

\section{INTRODUCTION}

Sunscreen compound octyl pmethoxycinnamate can be synthesized from ethyl $p$-methoxycinnamate by esterification reaction, either directly or through intermediate compounds. Direct esterification between a carboxylic acid with an alcohol (Fessenden \& Fessenden, 1989). Direct esterification reaction has been used in the synthesis of octyl $p$-methoxycinnamate of ethyl $p$ methoxycinnamate, after previously ethyl $p$ methoxycinnamate hydrolyzed into $p$ methoxycinnamic acid. This reaction produces octyl $p$-methoxycinnamate as much as $71.40 \%$ (Hidajati, 1997).

Other esterification reaction through intermediate compounds is a reaction that occurs between an acid halide with an alcohol
(Fessenden and Fessenden, 1989). This method requires a longer reaction stage.

In addition to esterification, the another synthesis of an ester known as transesterification, i.e. the ester formation reaction of another ester (Mc Murry J., 2008). Ethyl p-methoxy cinnamate compound is an ester, which allows the use of methods of transesterification in the synthesis of octyl $p$-methoxycinnamate in one step reaction.

*Corresponding author e-mail: suzanarushadi@yahoo.com 
<smiles>CCCCCOC(=O)/C=C/c1ccc(OC#CC(=O)OCCOc2ccc(OC)cc2)cc1</smiles>

Ethyl p-methoxycinnamate

Octyl p-methoxycinnamate

Figure I. Steps of the Synthesis of Octyl p-Methoxycinnamate

In consideration of the reaction path that is shorter, so hopefully obtain more results, hence in this study we used the method of transesterification.

\section{MATERIALS AND METHODS}

Isolation of ethyl p-methoxycinnamate of rhizome kencur (Kaempferia galanga L.)

Rhizome powder kencur (Kaempferia galanga L.) was percolated with $96 \%$ ethanol for \pm 24 hours. Solvent of the percolate was evaporated with Rotary vacuum evaporator, and then cooled to obtain crystals of ethyl p-methoxycinnamate. The crystals was washed with methanol and recrystallized with methanol-water (Hidajati, 1997).

\section{Synthesis of octyl $p$-methoxycinnamate}

Into a round bottom flask put $500 \mathrm{mg}$ of ethyl $p$-methoxycinnamate, $10 \mathrm{ml}$ octanol and 0.5 $\mathrm{ml}$ of sulfuric acid, shake until the crystal dissolve.. The mixture was refluk for 7.5 hours with the temperature $150{ }^{\circ} \mathrm{C}$. To remove any residual reagents, the mixture were distilled fraction in vacuum. The residue was extracted with hexane. The extract obtained is purified by column chromatography. Stationary phase used was silica gel $\mathrm{G} 60 \mathrm{~F}_{254}$ and used n-hexane: ethyl acetate: acetone $(65: 15: 5)$ as eluent.

\section{Identification structure of ethyl $p$ - methoxycinnamate and octyl $p$ - methoxycinnamate}

Identification of ethyl $p$-methoxycinnamate was done by determination of melting point using a Electrothermal Melting Point Apparatus; Thin Layer Chromatography with stationary phase silica gel $\mathrm{G} 60 \mathrm{~F}_{254}$ and 3 kinds of mobile phase, respectively = hexane: ethyl acetate: acetone (65: 15: 5) , hexane: chloroform: acetic acid (5:4:1), hexane: ethyl acetate (4: 1), with ultraviolet light as the detection; infrared spectrophotometer, UV spectrophotometer, mass spectrometer.

\section{Determination of \% T erythema and \%T pigmentation}

Created a solution of octyl pmethoxycinnamate in methanol with various concentrations $(5,10,15,20,25,30,35,40 \mathrm{ppm})$, and then measuredita transmition at a wavelength of 292 to $372 \mathrm{~nm}$ with intervals of $5 \mathrm{~nm}$ using UVVIS spectrophotometer. Were determined with Cumpelik method the size \% T erythema and \% T pigmentation (Dinunzio, 1990; Cumpelik, 1972; Kreps, 1972).

\section{RESULTS AND DISCUSSION}

In this research, 2 (two) steps of research is the isolation of ethyl $p$-methoxycinnamate from rhizome kencur and transesterifikasi reaction octanol and ethyl $p$-methoxycinnamate. Isolation of ethyl $p$-methoxycinnamate of rhizome kencur done by percolation using ethanol $96 \%$. The resulting crystals purified by recrystallization using a solvent mixture of methanol-water, to obtain white needle crystals which have a melting range $47-48{ }^{\circ} \mathrm{C}$, whereas according to literature from melting range of $48-48.5^{\circ} \mathrm{C}$ (Tanjung, 1997). From this isolation is obtained ethyl $p$ methoxycinnamate $1.25 \%$ of the dry weight of rhizome kencur (Kaempferia galanga L.), in the form of needle crystals, white and odorless.

Transesterification reaction of octyl $p$ methoxycinnamate with early material gives ethyl $p$-methoxycinnamate percent yield was $87.40 \%$, solid, cream-colored with a melting point of 28.5 ${ }^{\circ} \mathrm{C}$.

The purity by TLC using silica gel $\mathrm{G}_{60} \mathrm{~F}_{254}$ stationary phase and stain showing used UV light. Rf value TLC results of octyl $p$ methoxycinnamate and ethyl $p$-methoxycinnamate can be seen in Table I. 
Table I. Rf value TLC results of octyl p-methoxycinnamate and ethyl p-methoxycinnamate with used UV light as detection

\begin{tabular}{lcc}
\hline \multicolumn{1}{c}{ Eluent } & $\begin{array}{c}\text { ethyl } \mathbf{p} \text { - } \\
\text { methoxycinnamate }\end{array}$ & $\begin{array}{c}\text { Value R } \\
\text { methoxycinnamate }\end{array}$ \\
\hline $\begin{array}{l}\text { hexane : ethyl acetate : acetone } \\
(65: 15: 5)\end{array}$ & 0,66 & 0,76 \\
$\begin{array}{l}\text { hexane }: \mathrm{CHCl}_{3}: \text { glacial acetic } \\
\text { acid }(5: 4: 1)\end{array}$ & 0,90 & 0,92 \\
hexane : ethyl acetate $(4: 1)$ & 0,73 & 0,84 \\
\hline
\end{tabular}

Identification of isolates by UV-Vis spectrophotometer to give the peak wavelength of maximum absorbance at $225 \mathrm{~nm}$ and $307 \mathrm{~nm}$, in accordance with earlier research that ethyl $p$ methoxycinnamate to provide maximum absorption peak at wave 225 and $307 \mathrm{~nm}$ (Tanjung, 1997). Identification using an infrared spectrophotometer showed the existence of clusters $\mathrm{C}=\mathrm{O}$ ester at a wavelength of $1707 \mathrm{~cm}^{-1}$; ester CO group at $1168 \mathrm{~cm}^{-1}$ and $1253 \mathrm{~cm}^{-1}$ for bound aromatic ether groups. Identification by mass spetroscopy shows molecular weight 206. The compound was identical as ethyl $p$ methoxycinnamate.

Table. II. Characterization of UV spectra, IR and MS compound ethyl p-methoxyCinnamate

\begin{tabular}{|c|c|}
\hline $\begin{array}{l}\text { UV Spectrum; } \lambda \text { maximum }(\mathrm{nm}) \\
\text { In methanol solvent }\end{array}$ & 225 and 307 \\
\hline $\begin{array}{c}\text { IR Spectrum; } \lambda\left(\mathrm{cm}^{-1}\right) \\
\text { In } \mathrm{KBr} \text { pellet }\end{array}$ & $\begin{array}{c}\text { I } 707(\mathrm{C}=\mathrm{O} \text { ester }) \text {; I I } 68 \text { (-C-O- ether); } \\
\text { I } 253\left(\mathrm{CH}_{3} \mathrm{O} \text { - aromatis }\right)\end{array}$ \\
\hline Mass Spectrum $(\mathrm{m} / \mathrm{e})$ & $\begin{array}{c}78\left(\mathrm{C}_{6} \mathrm{H}_{5}++\mathrm{H}^{+}\right) ; 133\left(\mathrm{M}-\mathrm{COO}_{-} \mathrm{C}_{2} \mathrm{H}_{5}\right)^{+} ; \\
161\left(\mathrm{M}-\mathrm{OCC}_{2} \mathrm{H}_{5}\right)^{+} ; \mathrm{I} 79\left(\mathrm{M}-\mathrm{C}_{2} \mathrm{H}_{4}\right)^{+} ; 206(\mathrm{M})^{+}\end{array}$ \\
\hline
\end{tabular}

Identification of compounds synthesized using UV-VIS spectrophotometer to give the peak wavelength of maximum absorbance at $225 \mathrm{~nm}$ and $309 \mathrm{~nm}$. In the literature mentioned that in order to be used as a sunscreen compound must meet the criteria as a sunscreen compound that has a maximum wavelength between 270-360 nm-1 (group cinnamate) (Shaath, 1986). Identification with an infrared spectrophotometer data obtained wave number at $1712 \mathrm{~cm}^{-1}$ for group $\mathrm{C}=\mathrm{O}$ ester, $1168 \mathrm{~cm}^{-1}$ for $\mathrm{CO}$ ester and $1251 \mathrm{~cm}^{-1}$ for bound aromatic ethers. Identification of a mass spectrometer shows compounds synthesized has a relative molecular mass $(\mathrm{Mr})$ of 290. (Kemp.W., 1979; Silverstein RM, 1986). The compound was identical as octyl $p$-methoxycinnamate.

Table III. Characterization of UV spectra, IR and MS compound octyl pmethoxycinnamate

\begin{tabular}{|c|c|}
\hline $\begin{array}{l}\text { UV Spectrum; } \lambda \text { maximum }(\mathrm{nm}) \\
\text { In methanol solvent }\end{array}$ & 225 and 309 \\
\hline $\begin{array}{c}\text { IR Spectrum; } \lambda\left(\mathrm{cm}^{-1}\right) \\
\text { In } \mathrm{KBr} \text { pellet }\end{array}$ & $\begin{array}{c}\text { I7I2 (C=O ester); II68 (-C-O- ether); } \\
\left.\text { I25I ( } \mathrm{CH}_{3} \mathrm{O} \text { - aromatis }\right)\end{array}$ \\
\hline Mass Spectrum $(\mathrm{m} / \mathrm{e})$ & $\begin{array}{c}77\left(\mathrm{C}_{6} \mathrm{H}_{5}++\mathrm{H}^{+}\right) ; \mathrm{I} 33(\mathrm{M}-\mathrm{COO}-\text { Octyl) } \\
\text { I6I }(\mathrm{M}-\mathrm{O}-\mathrm{Octyl})^{+} ; \\
\mathrm{I} 78\left(\mathrm{M}-\mathrm{CH}_{2}=\mathrm{CH}-\mathrm{C}_{6} \mathrm{H}_{13}\right)^{+} ; 290(\mathrm{M})^{+}\end{array}$ \\
\hline
\end{tabular}

Transesterification reaction is a reversible reaction. To prevent the reaction shifted to the left in order to get maximum results by using excess alcohol or eliminate the side product (Fessenden, 1992; Morrison and Boyd, 1989). In this research, to prevent the reaction shifts to the left of excessive alcohol use (about twenty-six times the number of moles required). The excess of alcohol was removed by vacuum fractional distillation.
Distillation fraction is intended to remove excess alcohol boiling point difference with the compounds synthesized are very small (n-octanol boiling point $178-180{ }^{\circ} \mathrm{C}$ ). While the vacuum performed for synthesized compounds are not damaged or broken down due to high heat. With a vacuum at a pressure of $9 \mathrm{~mm} \mathrm{Hg}$, then the noctanol was separate with a relatively low boiling point of $48-52{ }^{\circ} \mathrm{C}$. 
Removal of excess n-octanol quite difficult, because of difficulties in removal of excess alcohol in the transesterification method is less efficient than the method of esterification step (esterification via acylation reaction) using alcohol with molecular ratio of 1:1 (Vogel, 1986). The result of the determination of $\% \mathrm{~T}$ erythema and $\% \mathrm{~T}$ pigmentation octyl $\mathrm{p}$-methoxy-cinnamate can be seen in Table IV.

Table IV. The result of the determination of \%T erythema and \%T pigmentation octyl p-methoxycinnamate

\begin{tabular}{ccc}
\hline Concentration (ppm) & \%T erytema & \%T pigmentation \\
\hline 5 & 71,05 & 90,76 \\
10 & 50,54 & 83,34 \\
15 & 44,21 & 82,72 \\
20 & 30,98 & 77,09 \\
25 & 19,36 & 72,49 \\
30 & 16,74 & 62,58 \\
35 & 11,15 & 63,45 \\
40 & 9,19 & 64,57 \\
50 & 4,01 & 57,65 \\
60 & 2,60 & 54,36 \\
70 & 1,27 & 62,34 \\
\hline
\end{tabular}

Table V. Clasification of compounds sunscreen octyl p-methoxycinnamate

\begin{tabular}{|c|c|c|c|}
\hline \multirow{2}{*}{$\begin{array}{c}\text { Concentration } \\
\text { octyl p-methoxycinnamate } \\
\text { (ppm) }\end{array}$} & \multirow{2}{*}{$\begin{array}{l}\text { Classification } \\
\text { product }\end{array}$} & \multicolumn{2}{|c|}{ Literature } \\
\hline & & \%T Erytema & $\begin{array}{c}\% \mathrm{~T} \\
\text { Pigmentation }\end{array}$ \\
\hline$>70$ & Total blocks & $<1 \%$ & $3-40 \%$ \\
\hline $50-70$ & Extra protection & $1-6 \%$ & $42-86 \%$ \\
\hline $35-40$ & Suntan fixed & $6-12 \%$ & $45-86 \%$ \\
\hline$<35$ & Tanning rapidly & $10-18 \%$ & $45-86 \%$ \\
\hline
\end{tabular}

Classification of compounds sunscreen octyl $p$-methoxycinnamate based on $\% \mathrm{~T}$ erythema and $\% \mathrm{~T}$ pigmentation can be seen in Table $\mathrm{V}$. The calculation of the coefficient extingsi octyl pmethoxycinnamate molar yield of 15 544. Based on the $\% \mathrm{~T}$ erythema and $\% \mathrm{~T}$ pigmentation sunscreen compounds can be grouped into a total block, extra protection, suntan tanning equipment and fast (Kreps, 1972).

From the value of $\% \mathrm{~T}$ erythema and $\% \mathrm{~T}$ pigmentation, octyl p-methoxycinnamate can function as a sunscreen compound with the classification type of extra protection at a concentration of 50-70 ppm, the type of suntan fixed at a concentration of 35-40 ppm and the type of tanning rapidly at concentrations $<35 \mathrm{ppm}$ and at concentrations $>70 \mathrm{ppm}$ as total blocks.

\section{CONCLUSIONS}

The ethyl acetate extract of Aspergillus brevipes RK06 showed growth inhibition against Klebsiella pneumonia, Pseudomonas aeruginosa, and Staphylococcus aureus. Based on the assays, the extract showed a potential citotoxity and both low antioxidant and hemolytic activities.

1. Synthesis of compounds sunscreen octyl pmethoxycinnamate can be done through a transesterification reaction between n-octanol with ethyl p-methoxycinnamate with hail percent amounting to $87.40 \%$.

2. From the value of $\% \mathrm{~T}$ erythema and $\%$ pigmentation, octyl p-methoxycinnamate can function as a sunscreen compound with the classification type of extra protection at a concentration of 50-70 ppm, the type of suntan fixed at a concentration of $35-40 \mathrm{ppm}$ and the type of tanning rapidly at concentrations $<35 \mathrm{ppm}$ and at concentrations $>70 \mathrm{ppm}$ as a total block.

\section{REFERENCES}

Anonim, 1985, Tanaman Obat Indonesia, Jilid II, Dep. Kes. R.I., Jakarta, pp.82. 
Cumpelik, B.M., 1972, Analitycal Procedures and Evaluation of Suncreen, J. Soc. Cosmet. Chemist, 2, 333-345.

Dinunzio, J.E. and Gadde, R.R., 1990, Determination of Sunscreen Compounds in Topical Sunsscreen Products, J. of Chromatography A, I, I I7-I 24.

Fessenden, J.R. and Fessenden J.S, 1989, Kimia Organik, Jilid I, Edisi 3, Erlangga, Jakarta, Pp. 631.

Hidajati, N., 1997, Sintesis Oktil p-metoksisinamat dan 2-etilheksil $p$-metoksisinamat dari etil pmetoksisinamat hasil isolasi Kaempferia galanga L, Tesis, Universitas Airlangga, Surabaya.

Kemp. W., 1979, Organic Spectroscopy, The Macmillan Press, London.

Kreps, S.I. and Goldenberg, 1972, Suntan Preparation in Balsam MS, Cosmetic Science and Technology, 2nd Ed., John Wiley \& Sons, Inc., Pp. 24I-305.

Mc Murry, J., 2008, Organic Chemistry, Seventh Edition, Thomson Learning Inc. United State, pp. 797, 809,820.

Shaath, 1986, The Chemistry of Suncreen, Cosmetic Toiletries, I 0 I (3), 55-70.

Silverstein, R.M., Bassler, B.C. and Morille, 1986, Penyidikan Spektrofotometrik Senyawa Organik (Terjemahan Hartono J., Anny V.P.) edisi IV, Erlangga, Jakarta. pp. 95-169, 305-319.

Tanjung, M., 1997, Isolasi dan Rekayasa Senyawa Turunan Sinamat dari Kaempferia Galanga L. sebagai Tabir Surya, Lembaga Penelitian Universitas Airlangga, Surabaya.

Vogel, A.I., 1986, A Text Book of Practical Organic Chemistry, fifth ed., Longman, London. 